Research Article

\title{
Ginsenoside Rg1 Improves Differentiation by Inhibiting Senescence of Human Bone Marrow Mesenchymal Stem Cell via GSK-3 $\beta$ and $\beta$-Catenin
}

\author{
Ziling Wang, ${ }^{1}$ Rong Jiang, ${ }^{1}$ Lu Wang, ${ }^{1}$ Xiongbin Chen, ${ }^{1,2}$ Yue Xiang, ${ }^{1}$ Linbo Chen, \\ Minghe Xiao, ${ }^{1}$ Li Ling, ${ }^{3}$ and Yaping Wang ${ }^{1}$ \\ ${ }^{1}$ Department of Histology and Embryology, Laboratory of Stem Cells and Tissue Engineering, Chongqing Medical University, \\ Chongqing 400016, China \\ ${ }^{2}$ Department of Anatomy and Histology and Embryology, Basic Medical College, Chengdu University of Traditional \\ Chinese Medicine, Sichuan 610075, China \\ ${ }^{3}$ Department of Obstetrics and Gynecology, The Second Affiliated Hospital of Chongqing Medical University, \\ Chongqing 400010, China
}

Correspondence should be addressed to Yaping Wang; 469892855@qq.com

Received 25 March 2020; Revised 27 April 2020; Accepted 8 May 2020; Published 26 May 2020

Academic Editor: Valeria Sorrenti

Copyright (C) 2020 Ziling Wang et al. This is an open access article distributed under the Creative Commons Attribution License, which permits unrestricted use, distribution, and reproduction in any medium, provided the original work is properly cited.

\begin{abstract}
Objectives. To demonstrate the effect of Ginsenoside Rg1 on the differentiation of human bone marrow-derived mesenchymal stem cells (hBM-MSCs). Subsequently, a rational mechanism for the detection of Rg1 which affects mesenchymal stem cell differentiation was explored. Methods. Flow cytometry is used for cell identification. The differentiation ability of hBM-MSCs was studied by differentiation culture. SA- $\beta$-gal staining is used to detect cell senescence levels. Western blot and immunofluorescence were used to determine protein expression levels. RT-qPCR is used to detect mRNA expression levels. Results. Rg1 regulates the differentiation of hBM-MSCs. Differentiation culture analysis showed that Rg1 promoted cells to osteogenesis and chondrogenesis. Western blot results showed that $\operatorname{Rg} 1$ regulated the overactivation of the $\beta$-catenin signaling pathway and significantly adjusted the phosphorylation of GSK-3 $\beta$. GSK-3 $\beta$ inhibitor (Licl) significantly increased Rg1-induced phosphorylation of GSK-3 $\beta$, which in turn reduced Rg1-induced differentiation of hBM-MSCs. Conclusion. Ginsenoside Rg1 can reduce the excessive activation of the Wnt pathway in senescent cells by inhibiting the phosphorylation of GSK-3 $\beta$ and regulate the mesenchymal stem cell differentiation ability.
\end{abstract}

\section{Introduction}

Adult stem cell senescence is the latest theory of the occurrence and development of human aging and senile diseases [1-4]. Stem cells can maintain and control the homeostasis of a normal body $[5,6]$, the aging of stem cells which leads to the degeneration of body structure and function, and the occurrence of related senile diseases. For the prevention and treatment of senile degenerative diseases, it is of great value to study the mechanism and control measures of stem cell aging and to find ways to stimulate stem cell activity. Mesenchymal stem cells (MSCs) are derived from the mesoderm and can proliferate and differentiate into fibroblasts, reticular cells, macrophages and endothelial cells, fat cells, osteoblasts, and hematopoietic stromal cells [7]. Previous studies $[8,9]$ have proved that with the increase of age, hBM-MSCs will show dynamic aging biological changes and then accompany the occurrence and development of senile diseases.

Panax ginseng is a traditional Chinese medicine to replenish "qi”. According to Shen Nong's Herbal Classic [10], P. ginseng can "tonify organs, reduce the eclampsia, improving eyesight, good for the brain, and remove evil spirits", and "consistent and correct use of P. ginseng can prolong life". Modern medical research and laboratory analysis also show [11-13] that ginsenoside Rg1 is an important 
chemical monomer in P. ginseng, which has obvious effects on regulating people's central nervous system, cardiovascular system, antifatigue, and regulating material metabolism. This research group has long been committed in combining the traditional Chinese medicine concept and stem cell theory and striving to find a way to delay the aging of the body through the collision of the traditional "qi and blood" theory and the stem cell theory, so as to make the body "healthy when old" and avoid the "premature aging of the body". Previous studies [14-17] have shown that ginsenoside Rg1 can antagonize the oxidative damage of the body and regulate the aging of neural stem cells and hematopoietic stem cells by affecting the oxidative stress mechanism of cells. So, can ginsenoside $\mathrm{Rg} 1$ regulate the aging of human bone marrow mesenchymal stem cells? What is the possible mechanism?

The Wnt/ $\beta$-catenin signaling pathway is an important stem-cell related pathway [18]. The Wnt pathway is conserved during evolution and has a wide range of biological functions during development [19-21]. It has been reported [22-25] that the activation level of the $\beta$-catenin signaling pathway is closely related to the level of stem cell senescence. In our previous studies [26-28], we found that stem cell senescence is due to changes in the living environment of stem cells and is due to changes in the signaling pathways associated with changes in stem cell microenvironment. Among them, the changes of the $\beta$-catenin signaling pathway have a wide and important relationship with changes in stem cell function. Recent studies $[24,29,30]$ have shown that the $\beta$-catenin signaling pathway has a wide range of biological effects on hematopoietic stem cell senescence, and hematopoietic stem cell senescence can be produced by overactivation of the $\beta$-catenin signaling pathway. In contrast, inhibition of the $\beta$-catenin signaling pathway can attenuate the senescence of hematopoietic stem cells. So, is aging of human bone marrow mesenchymal stem cells (hBM-MSCs) associated with the $\beta$-catenin signaling pathway?

In the current study, the effect of Rg1 on the differentiation of hBM-MSCs was determined, and the roles of the $\mathrm{Wnt} / \beta$-catenin signaling pathway were studied. These findings may support the use of Rg1 in promoting stem cell viability and differentiation, as well as in tissue engineering and clinical therapy.

\section{Materials and Methods}

2.1. Isolation and Culture of hBM-MSCs. Human bone marrow-derived mesenchymal stem cells were isolated from the bone marrow. The bone marrow from healthy donors aged 18 to 80 ( $n>20 /$ group) was collected from volunteers who received bone marrow puncture at the First Affiliated Hospital of Chongqing Medical University, China. The study was approved by the ethics committee of Chongqing medical university.

The bone marrow cells were mixed with the red blood cell cracking liquid and the sedimentation (volume $5: 1$ ) at $4^{\circ} \mathrm{C}$ for $5 \mathrm{~min}$. Mononuclear cells were separated from the residue by using an isolated lymphocyte separation medium. The isolated hBM-MSCs were resuspended in DMEM/F12 supple- mented with $10 \%$ FBS, $1 \%$ penicillin, and $1 \%$ streptomycin. Cells were cultured at a density of $5 \times 10^{5} / \mathrm{cm}^{2}$ in a humidified environment at $37^{\circ} \mathrm{C}$ with $5 \% \mathrm{CO}_{2}$. After about 20 to $25 \mathrm{~d}$, the cells were cultured and fused at 90 to 100 percent, followed by subculture. Passage cells were carried every 7$10 \mathrm{~d}$. The third and sixth sections of hBM-MSCs (p3-p6) were used for the experiment. The growth and morphology of the cells were observed with an inverted microscope (Olympus Corporation, Tokyo, Japan).

2.2. Flow Cytometry. Flow cytometry was used to detect the expression of hBM-MSC surface antigen markers. The cells $\left(>1 \times 10^{6}\right.$ in each group) of each group were suspended in PBS containing 2\% BSA, fluorescein isothiocyanate- (FITC) labeled or phycoerythrin- (PE-) labeled specific antibodies FITC-CD105, FITC-CD45, FITC-CD34, FITC-CD19, FITC-CD14, FITC HLA-DR, FITC-CD90, PE-CD73, PE$\mathrm{CD} 11 \mathrm{~b}$ which were incubated in accordance with the specification at $4^{\circ} \mathrm{C}$ for $30 \mathrm{~min}$ in dark. The results were used Cell Quest software for data processing.

2.3. Optimization of Rg1 Treatment Protocol and Dosage. The Rg1 was purchased from Jilin Hongjiu Biotechnology Co. Ltd. Rg1 is white solid powder, slightly soluble in water, and soluble in DMSO. Thus, Rg1 is configured with a high concentration of DMSO solution. Cells in the Rg1 group were exposed to Rg1, and cells in the control group received pseudotreatment (without Rg1). The optimal concentration and time of the drug were determined by a CCK- 8 method and cell proliferation analysis.

2.4. EdU Assay. HBM-MSCs were inoculated in 24-well plates at a concentration of $1.5 \times 105 / \mathrm{mL}$ and cultured in Edu solution for $24 \mathrm{~h}$. $4 \%$ paraformaldehyde was fixed $30 \mathrm{~min}$ at room temperature. Washed cells were permeabilized $0.5 \%$ Triton X-100 for $20 \mathrm{~min}$. Then, the cells were incubated with 1X Apollo ${ }^{\circledR}$ reaction cocktail for $30 \mathrm{~min}$ and stained using 1X Hoechst33342 for $30 \mathrm{~min}$ and imaged under a fluorescent microscope (Olympus Corporation). The proliferation rate was defined as the ratio of Edu-positive cells (labeled red fluorescence) to hoechst33342-positive cells (labeled blue fluorescence).

2.5. Senescence-Associated $\beta$-Galactosidase (SA- $\beta$-Gal) Staining. The SA- $\beta$-gal staining was performed according to the manufacturer's instructions. Cells were prepared as previously described, fix in $4 \%$ paraformaldehyde for 5 minutes, washed twice with PBS, and plastic wrap sealed in a dyeing box, stained at $37^{\circ} \mathrm{C}$ overnight. The cytoplasm stained blue is senescent cells. Collection of images was done by an inverted microscope and optical density analysis by Image-Pro Plus 6.0 software.

\subsection{In Vitro Differentiation}

2.6.1. Osteogenesis. When the cell adherence rate reached $50 \%-70 \%$, the conventional medium was replaced with ODM, and the culture was replaced with ODM every $3 \mathrm{~d}$ for $21 \mathrm{~d}$. Rg1 was added to ODM media in the Rg1 treatment group for 21 days. After $21 \mathrm{~d}$, it was soaked in $4 \%$ 
paraformaldehyde for $30 \mathrm{~min}$ and washed with PBS for 3 times. Then, $1 \%$ alizarin red $\mathrm{S}(\mathrm{pH}=4.2)$ was used for 5 minutes.

2.6.2. Adipogenesis. When cell adherent reached $100 \%$, use ADM instead of conventional culture medium, replace ADM culture every $3 \mathrm{~d}$, and cultivate for $21 \mathrm{~d}$. Rg1 was added to ADM media in the Rg1 treatment group for 21 days. After $21 \mathrm{~d}$, the cells were washed with $4 \%$ paraformaldehyde for $30 \mathrm{~min}$ and washed with PBS for 3 times. Then, dye with oil red $\mathrm{O}$ for 60 minutes.

2.6.3. Chondrogenesis. When cell adherent reached 70\%-80\%, use CDM instead of conventional culture medium, replace CDM culture every $3 \mathrm{~d}$, and cultivate for $21 \mathrm{~d}$. Rg1 was added to CDM media in the Rg1 treatment group for 21 days. After $21 \mathrm{~d}$, the cells were washed with $4 \%$ paraformaldehyde for $30 \mathrm{~min}$ and washed with PBS for 3 times. Then, dye with Alcian blue for 30 minutes.

Differentiation kits and staining solution were purchased from Cyagen Biosciences Inc. (Suzhou, China). Images were observed and collected using an inverted microscope (Olympus Corporation).

2.7. Immunofluorescence Staining. Cells prepared as previously described were fixed by $4 \%$ paraformaldehyde for 20 mins. After washing with $0.5 \%$ Triton X-100 for $20 \mathrm{~min}$, blocking with $10 \%$ goat serum was done for $30 \mathrm{mins}$ at room temperature. Then, the cells were incubated with antibodies against $\beta$-catenin $(1: 100)$ overnight at $4^{\circ} \mathrm{C}$. In the next day, the cells were warmed at room temperature for $30 \mathrm{mins}$ and washed three times. Then, the cy3-labeled secondary antibody $(1: 300)$ was incubated at $37^{\circ} \mathrm{C}$ for $1 \mathrm{~h}$. DAPI is used for nuclear staining. All slides were observed directly under a fluorescence microscope (LSM510; Carl Zeiss, Jena, Germany). Antibodies were purchased from Cell Signaling Technology Inc. (Boston, MA, USA).

2.8. Western Blot. Total protein was extracted by radioimmunoprecipitation, the lysate buffer was mixed with a $1 \%$ protease inhibitor cocktail (Beyotime Institute of Biotechnology), and the concentration was determined by the bicinchoninic acid method. Samples containing $40 \mathrm{~g}$ proteins were separated by $12 \%$ SDS PAGE and transferred to polyvinylidene fluoride membrane. At room temperature, it was sealed with skim milk powder ( $5 \%$ dissolved in TBS tween 20 ) for $2 \mathrm{~h}$, incubated overnight in $4^{\circ} \mathrm{C}(1: 1000$ diluted in primary antibody dilution buffer) with specific primary antibodies for $\beta$ catenin, GSK-3 $\beta, \beta$-actin (all from Cell Signaling Technology, Boston, MA, USA), LEF, TCF-4, and C-myc (all from Proteintech Group, Inc., China). Incubate at room temperature for 90 minutes with a secondary antibody $(1: 10000$ TBS-tween). Use an enhanced chemiluminescence detection system (Pierce; Thermo Fisher Scientific, Inc., Waltham, MA, USA), with $\beta$-actin ( $1: 1,000$ diluted antibody dilution buffer) as internal control. The integrated optical density was quantified by Image Lab 5.2.1 (Bio-Rad Laboratories, Inc., Hercules, CA, USA).
TABLE 1

\begin{tabular}{lc}
\hline SYBR $^{\circledR}$ premix Taq \\
PCII $(2 \mathrm{x})$ & $5 \mu \mathrm{L}$ \\
PCR forward primer $(10 \mu \mathrm{M})$ & $0.1 \mu \mathrm{L}$ \\
PCR reverse primer $(10 \mu \mathrm{M})$ & $0.1 \mu \mathrm{L}$ \\
cDNA & $2 \mu \mathrm{L}$ \\
RNase-free $\mathrm{dH}_{2} \mathrm{O}$ & $2.8 \mu \mathrm{L}$ \\
Total & $10 \mu \mathrm{L}$ \\
\hline
\end{tabular}

Reaction conditions: $95^{\circ} \mathrm{C} 30 \mathrm{~s}, 95^{\circ} \mathrm{C} 5 \mathrm{~s}, 60^{\circ} \mathrm{C} 30$ s, circle 40 times.

2.9. Real-Time Quantitative RT-PCR. Total RNA was isolated with trizol reagent (Invitrogen. USA) according to the manufacturer's agreement. The first strand of cDNA was constructed by TaqMan RT reagent (Applied Biosystems, USA). SYBR green Supermix (Bio-Rad) was used to perform real-time quantitative PCR on the circulator real-time detection system (Bio-Rad). The mRNA expression level and GAPDH were normalized, and the comparative cycle threshold method was used for analysis. The mean \pm standard deviation of three independent experiments was measured. The PCR primers used are provided in the supporting information (Tables 1 and 2).

2.10. Statistical Analysis. All data were expressed as mean \pm standard deviation. All statistical analyses were performed using one-way anova, and Fisher's least significant difference test was performed using SPSS v20.0 (IBM Corp., Armonk, NY, USA). $P<0.05$ was considered statistically significant.

\section{Results}

3.1. Conventional Bone Biopsy and Morphometric Determination. Bone marrow biopsy is a way to understand the bone marrow. However, the biopsy is more detailed and comprehensive than the puncture on the bone marrow status. For certain diseases, such as myelofibrosis, bone marrow punctures often fail due to "dry pumping", and bone marrow biopsy is often successful. We clinically collected patient biopsy specimens for Wright's staining. The content of each tissue was examined using morphometric software. The results (Figure 1) showed that with the increase of age, the proportion of hematopoietic tissue and trabecular bone tissue in bone marrow tissue decreased, and the proportion of adipose tissue increased.

3.2. The Identifying of hBM-MSCs. The cell morphology, the potential of multipotential differentiation, and the surface markers would be the key to identify the stem cells. Accordingly, experiments were under ways to ensure the validity of cells. The result of cell culture shows that the cells are generally elongated and spindle-shaped and its growth is characteristics of screw growth (Figure 2(b)). Adipogenic differentiation medium-induced hBMSC adipogenesis for $21 \mathrm{~d}$, the result, is shown in Figure 2(c). Chondrogenesis induction on day 21, the Alcan blue staining of hBMSCs, is shown in Figure 2(c). In Figure 2(a), here, is the flow cytometry pattern of the cell phenotype character of hBMSCs, which showed the cells are CD73+, CD90+, CD45-, CD34-, 
TABLE 2: Primers used in real-time quantitative PCR.

\begin{tabular}{lcc}
\hline$\beta$-Catenin & Forward & $5^{\prime}$-AAGCCACAAGATTACAAGAAACGG-3' \\
& Reverse & $5^{\prime}$-CCAAGATCAGCAGTCTCATTCCAA-3' \\
\hline \multirow{2}{*}{ LEF } & Forward & $5^{\prime}$-GAAATCATCCCAGCCAGCAA-3' \\
& Reverse & $5^{\prime}$-GGACCCATTTGACATGTACGG-3' \\
\hline \multirow{2}{*}{ C-myc } & Forward & $5^{\prime}$-GAGACAGATCAGCAACAACCGA-3' \\
& Reverse & $5^{\prime}$-CTGCTTGGACGGACAGGATG-3' \\
\hline \multirow{2}{*}{ TCF-4 } & Forward & $5^{\prime}$-GGAAAGAAGAAGAGGCGGTCA-3' \\
& Reverse & $5^{\prime}$-GCACTGTCATCGGAAGGAACG-3' \\
\hline \multirow{2}{*}{ GAPDH } & Forward & $5^{\prime}$-GCTACAGCTTCACCACCACAG-3' \\
& Reverse & $5^{\prime}$-GGTCTTTACGGATGTCAACGTC-3' \\
\hline
\end{tabular}
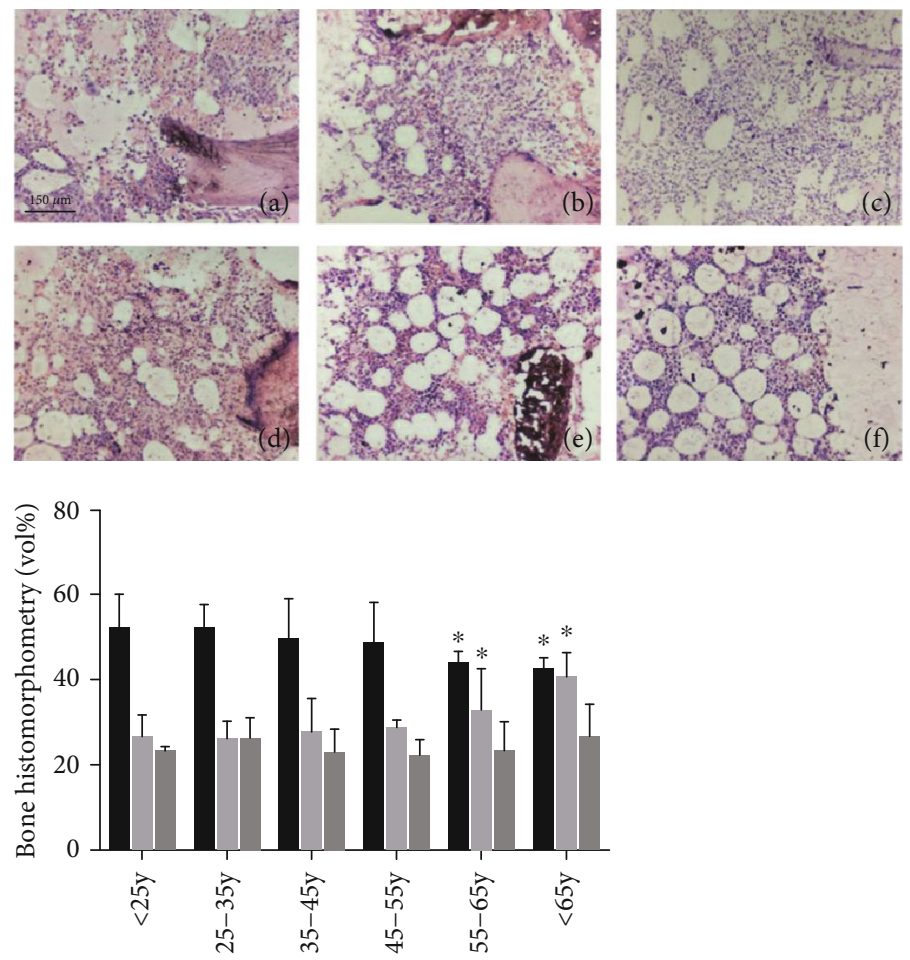

Hematopoietic tissue

Adipose tissue

Trabecular tissue

Figure 1: Conventional bone biopsy and morphometry. Bone marrow biopsy specimens from patients of different ages ( $n>20 /$ group) were collected for Wright staining. The amount of each tissue was checked using a morphometric software. The histogram shows the results of the morphometric measurements. (a) <25 years old group; (b) 25-35 years old group; (c) 35-45 years old group; (d) 45-55 years old group; (e) 55-65 years old group; and (f) $>65$ years old group.

CD14-, and HLA-DR-. All three analyses of cells identified showed these cells which had been purified and cultured are human mesenchymal stem cells $[23,31]$.

3.3. Determination of the Optimal Dose and Exposure Time of $\mathrm{Rg} 1$. In order to screen the optimal dose and exposure time of Rg1 for hBM-MSCs, we conducted CCK-8 experiment. In general, the mean OD value of the Rg1 group was higher than that of the control group ( $>65$ years old group) (Figure 3). The cell viability increased significantly in the Rg1 groups treated for $24 \mathrm{~h} \quad(P<0.05)$ as the $\mathrm{Rg} 1$ concentration increased. However, there were no significant differences between the obviously increased groups $(P>.05)$. At $48 \mathrm{~h}$, cells treated with $40 \mu \mathrm{M} \mathrm{Rg} 1$ had a significantly higher viability than that of the other group, while those treated with higher concentrations were not changed substantially. 

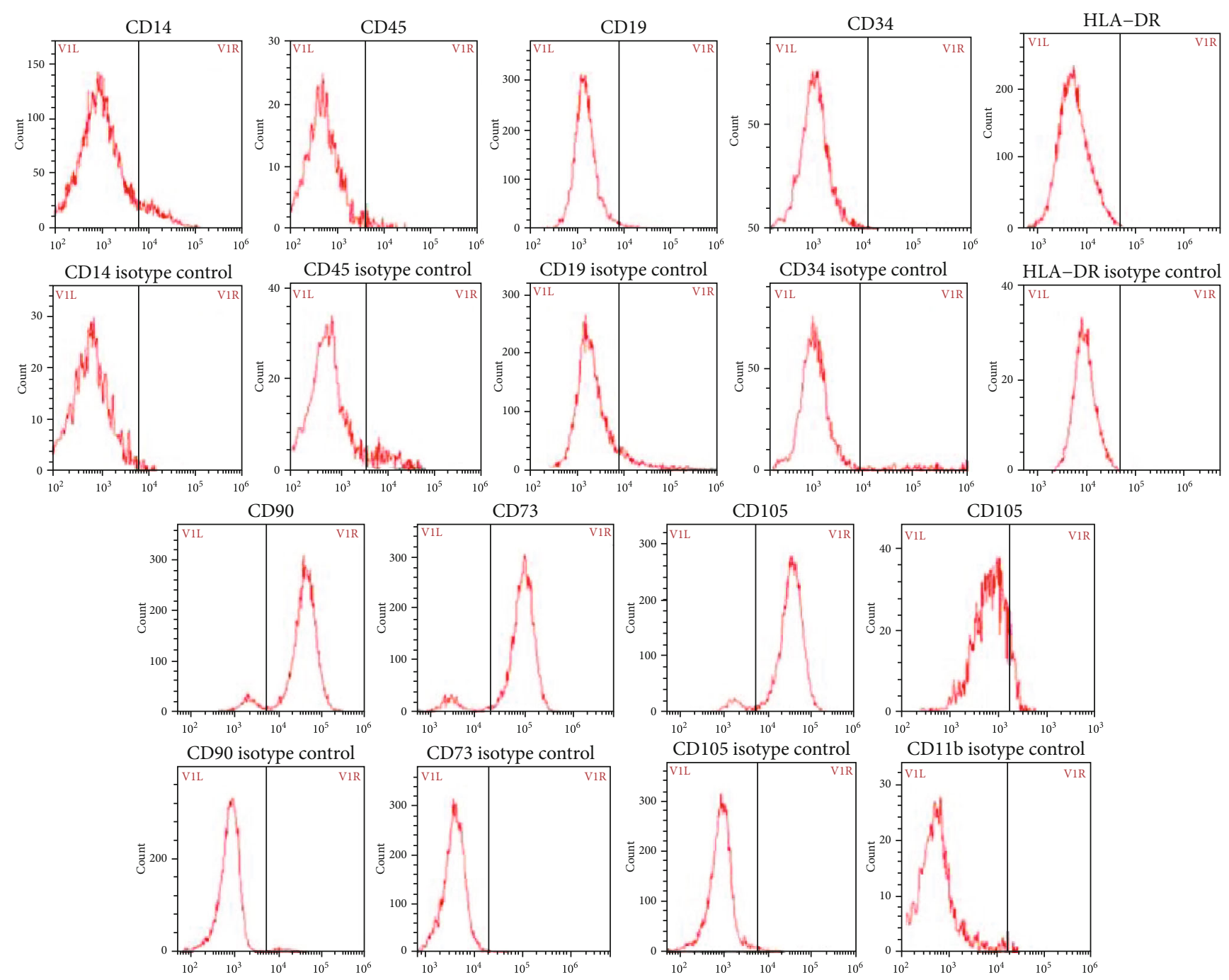

(a)
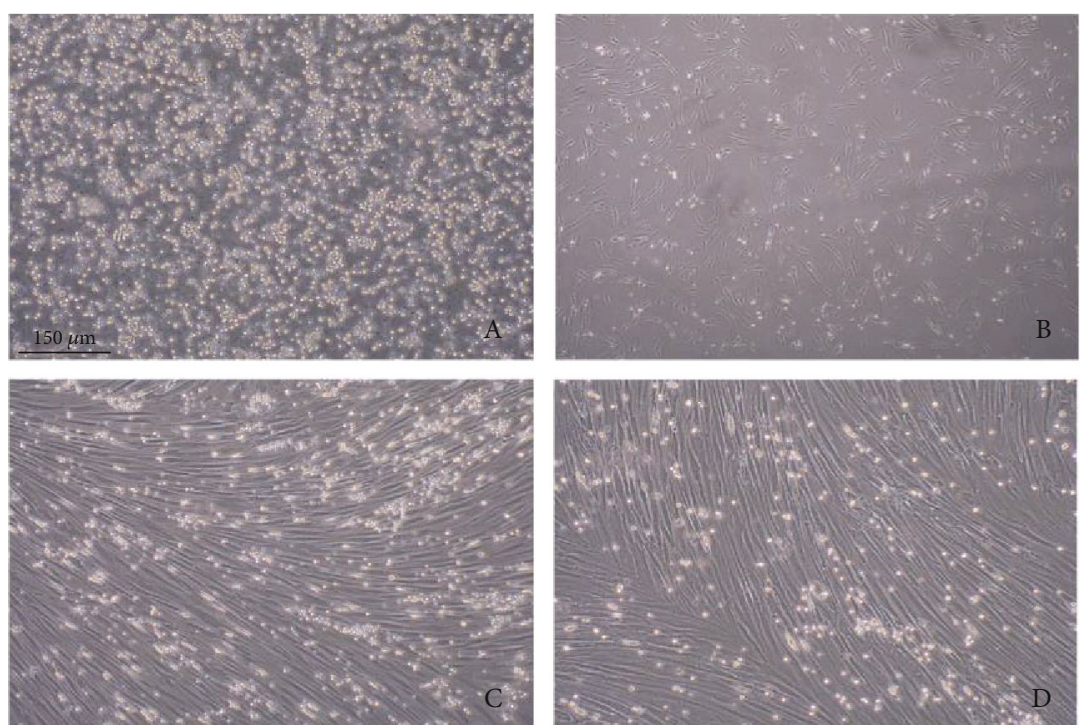

(b)

Figure 2: Continued. 

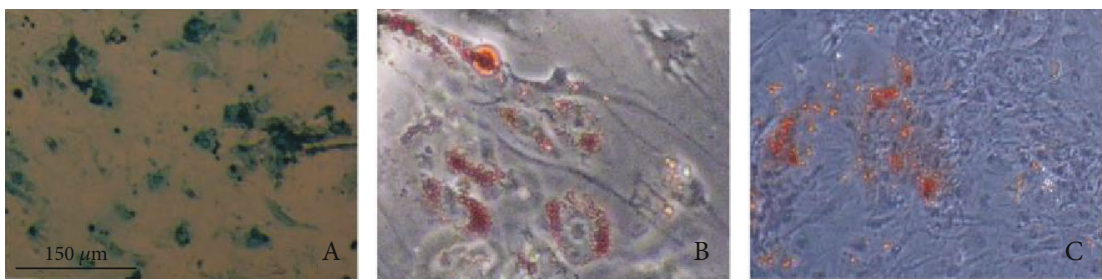

(c)

FIGURE 2: Identification of human bone marrow mesenchymal stem cells. Cells were identified by the surface markers, cell morphology, and differentiation ability. (a) The cells were stained with fluorescein isothiocyanate- (FITC-) or PE-conjugated antibodies or with immunoglobulin isotype control antibodies. (b) The morphology was observed using phase-contrast microscopy at different phases $(24 \mathrm{~h}$ (b-A), 3d (b-B), 14d (b-C), and subcultured hBM-MSCs (P3) (b-D), 100x). (c) The differentiation of hBM-MSCs, using induction medium inducing cells to chondrogenesis (c-A), lipoblast (c-B), and osteogenesis (c-C). Afterward, the special staining was used to detect the differentiation.
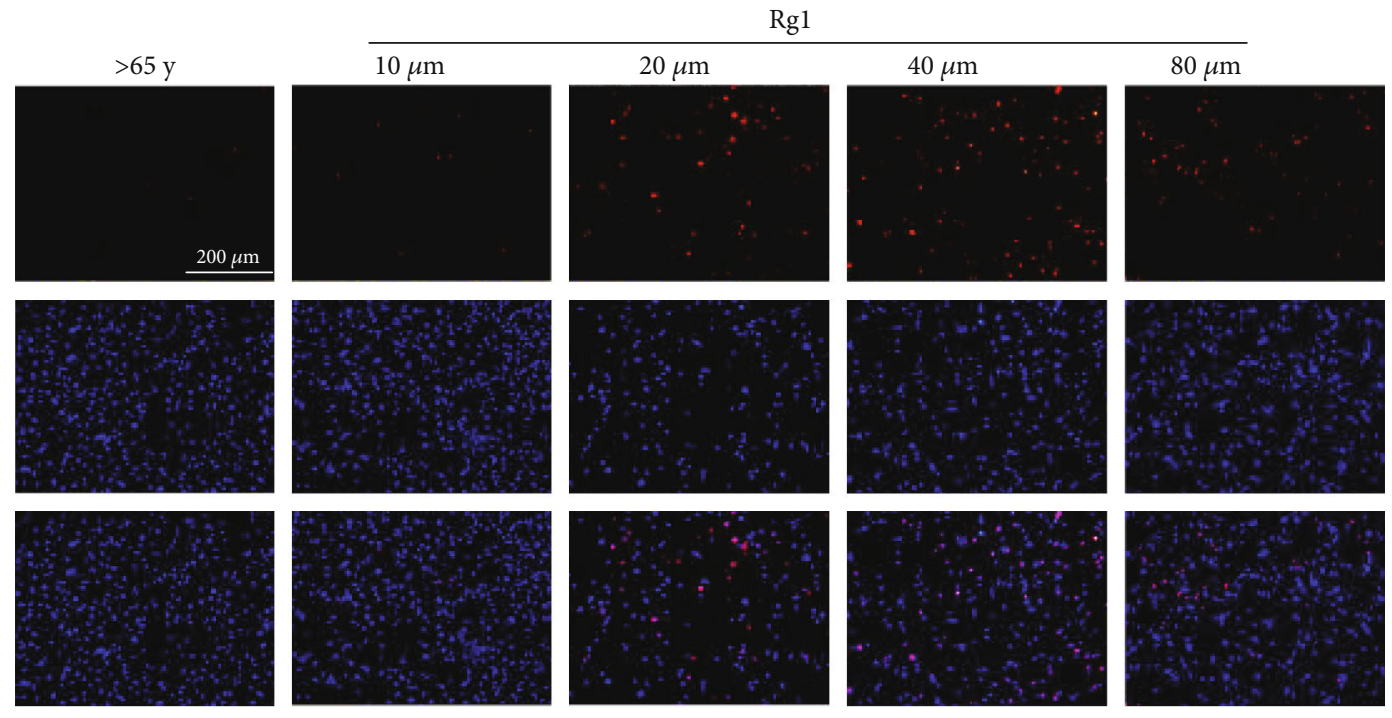

(a)


(b)

(c)

FIGURE 3: Effects of Rg1 on the growth of human bone marrow-derived mesenchymal stem cells (hBM-MSCs). The Rg1 group was treated with $\operatorname{Rg} 1$ in different concentrations and times, respectively. (a, b) Cell proliferation after treatment of senescent mesenchymal stem cells with different concentrations of Rgl. This test was repeated three times. Representative images were shown. (c) The growth curves of hBM-MSCs were measured by Cell Counting Kit-8 (CCK-8) assay. $* P<0.05, * * P<0.01$. 


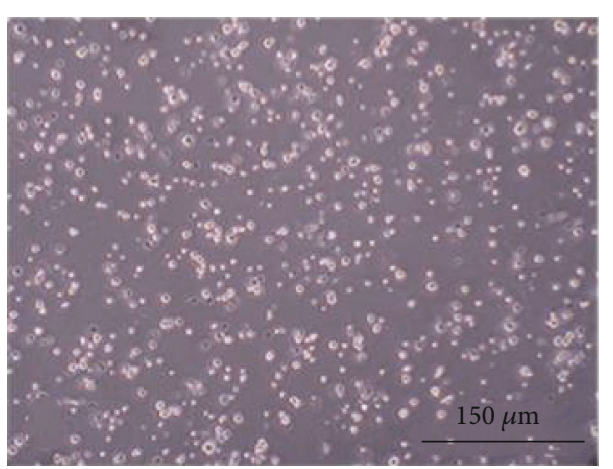

(a)

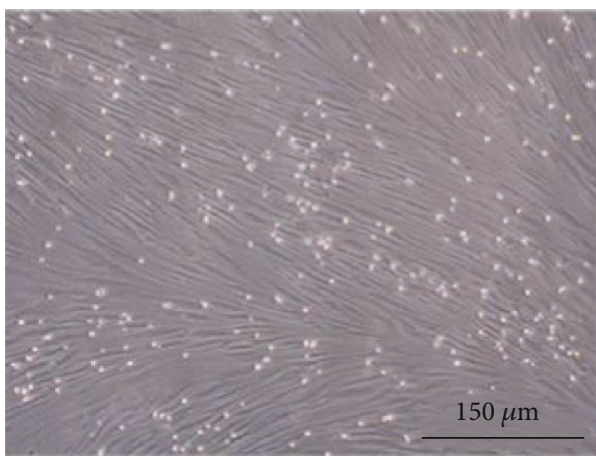

(c)

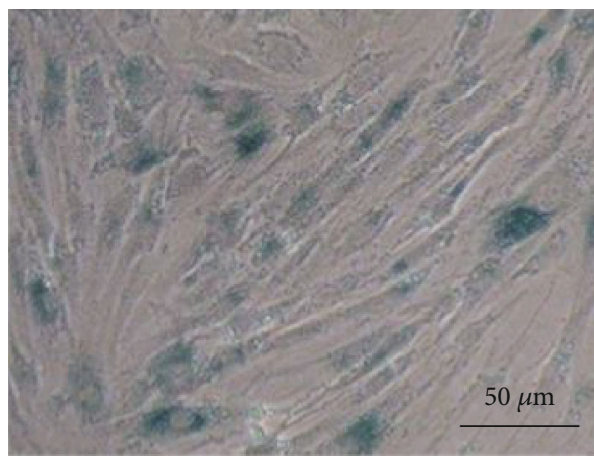

(e)

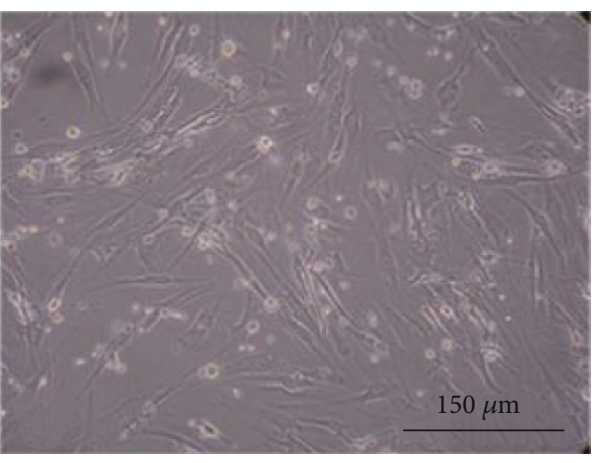

(b)



(d)

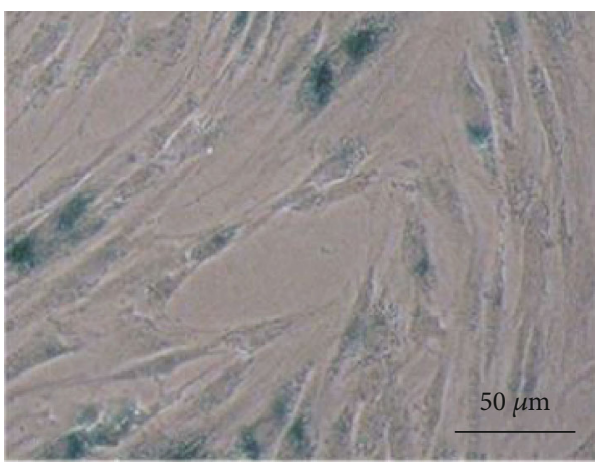

(f)

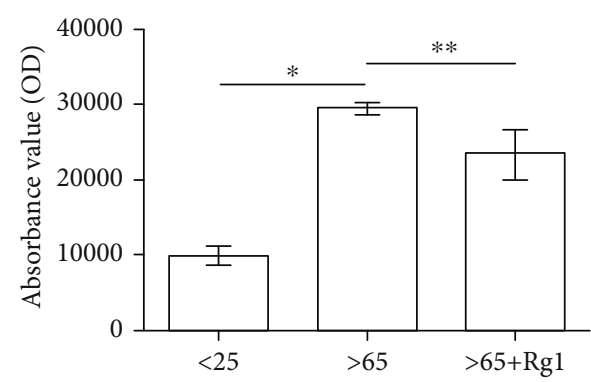

(g)

FIgure 4: Continued. 

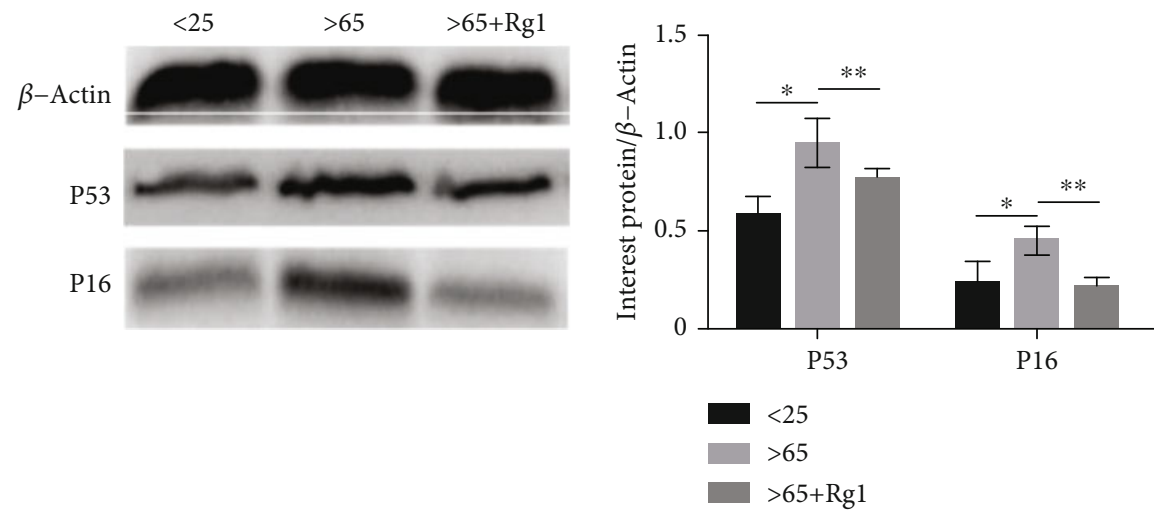

(h)

Figure 4: Effect of Rg1 on the senescence and morphology of hBM-MSCs. The cell morphology was observed at (a) $24 \mathrm{~h}$ and (b) $72 \mathrm{~h}$ and (c) cultured cells to the third generation after isolation. SA- $\beta$-gal was used to mark the aging cells the cytoplasm of positive cells was stained blue, (d) $<25$ years old, (e) $>65$ years old, and (f) $>65+\mathrm{Rg} 1$. This test was repeated three times. Representative images were shown. The ROD value was used to evaluate the intensity of SA- $\beta$-gal-positive staining $(\mathrm{g})$. Western blot was used to detect the protein expression of P53 and P16 (h). $\beta$-Actin was used as an internal control. $* * P<.05$ vs. $>65$-year-old group, $* P<.05$ vs. $<25$-year-old group. SA- $\beta$-gal: senescence-associated $\beta$-galactosidase; ROD: relative optical density.

Subsequently, hBM-MSC diffusion was studied by Edu in different groups, and the results showed that the proliferation of hBM-MSCs increased significantly when treated with Rg1 in $40 \mu \mathrm{M}$ at $48 \mathrm{~h}$.

3.4. Effects of Rg1 on Cell Morphology and Senescence. The bone marrow cultured an average of $4 \pm 1.18 \times 10^{7}$ per group. After $72 \mathrm{~h}, 60 \%-70 \%$ of hBM-MSCs were observed to adhere to the culture dish, and some spindle cells were observed (Figure 4(b)). 10-12 d later, hBM-MSCs were 90\% to $100 \%$ fused. The cells in passage culture also retained the shape of fibroblasts (Figure 4(c)). There was no significant change in cell morphology after treatment with Rg1.

The aging mesenchymal stem cells were dyed blue by using SA- $\beta$-gal staining [32] (Figures $4(\mathrm{~d})-4(\mathrm{f})$ ). The results showed that the positive rate of SA- $\beta$-Gal staining of hBMMSCs increased significantly in the aging group (Figure 4(e)). With the treatment of Rg1, the positive rate of SA- $\beta$-Gal staining of hBM-MSCs decreased (Figure 4(f)). This result indicates that Rg1 can retard the aging of hBMMSCs. The expression of P53 and P16 protein will increase during aging [33]. The results (Figure 4(h)) showed that Rg1 can decrease the expression of P53 and P16 protein.

3.5. Effects of Rg1 on Cell Differentiation Ability of hBMMSCs. With mesenchymal stem cells under certain conditions, it can be divided into a variety of functional cells. Studies [34-38] have reported that mesenchymal stem cells have the ability to differentiate into osteocytes, chondrocytes, and adipocytes. The strength of this ability is related to the "ability" of stem cells. The results showed that after osteogenic induction culture, Rg1 treatment of $>65$-year-old mesenchymal stem cells increased dark red nodules after alizarin red dye staining (Figure 5 (osteogenesis)), the fat-induced culture, Rg1 treatment of $>65$-year-old mesenchymal stem cells, and oil red $\mathrm{O}$ stained with red lipid material reduced (Figure 5 (fat formation)). In cartilage-induced culture,
Alcian blue-stained blue cartilage tissue increased after Rg1 treatment of >65-year-old mesenchymal stem cells (Figure 5 (cartilage)). The above results indicate that $\operatorname{Rg} 1$ can increase the osteogenic and chondrogenesis differentiation ability of mesenchymal stem cells in the $>65$-years-old group, which can reduce the adipogenic differentiation ability.

3.6. Rg1 Reduces Wnt/ $\beta$-Catenin Pathway Activation in Senile Mesenchymal Stem Cells. As a multifunctional protein, $\beta$-catenin is widely distributed in various types of cells [3941] and plays an important role in cell differentiation [39, $42,43]$. Western blot and immunofluorescence were performed to monitor the key proteins of the $\mathrm{Wnt} / \beta$-catenin signaling pathway. It was found that $\operatorname{Rg} 1(40 \mu \mathrm{M}, 48 \mathrm{~h})$ significantly reduced $\beta$-catenin, C-myc, LEF, and TCF-4 levels after treatment of senescent mesenchymal stem cells (Figures 6(d), 6(e), 6(g), and 6(h)). GSK-3 $\beta$ levels increased significantly (Figure 6(f)). The results showed that $\operatorname{Rg} 1$ reduced the activation of the $\beta$-catenin pathway in aging hBM-MSCs.

3.7. Rg1 Regulates hBM-MSC Differentiation and Is Associated with the Wnt/ $\beta$-Catenin Pathway. To determine whether the effect of $\operatorname{Rg} 1$ on the differentiation of aging hBM-MSCs depends on Wnt $\beta$-catenin signaling pathways, hBM-MSCs were pretreated with pathway activator Licl $(20 \mathrm{mM})$. The levels of $\beta$-catenin increased significantly and GSK-3 $\beta$ decreased significantly after pretreatment with Licl, indicating that Licl effectively activates the $\mathrm{Wnt} / \beta$-catenin pathway in hBM-MSCs.

Cell differentiation was assessed by an induction differentiation kit. The ability of osteoblast and chondrogenic differentiation in the Rg1-treated group was significantly higher than that in the Licl- (Rg1+activator) treated group and the control group (Figures $7(\mathrm{a})$ and $7(\mathrm{~b})$ ). The results showed that after Licl pretreatment, the expression of $\beta$-catenin, 

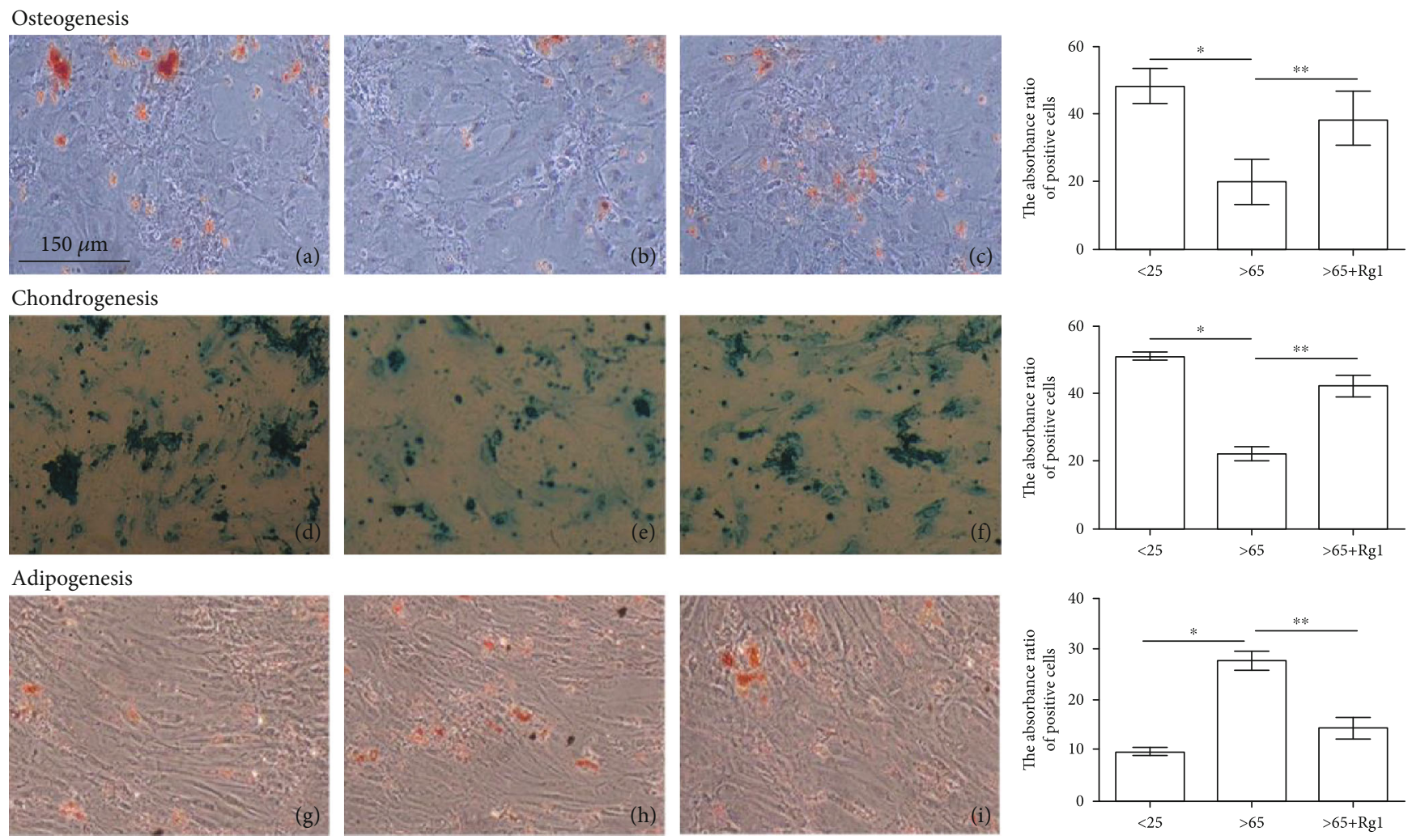

FIGURE 5: Differentiation potential of human bone marrow-derived mesenchymal stem cells (hBM-MSCs). After $21 \mathrm{~d}$ of culture in osteogenic $(a-c)$, or adipogenic $(d-f)$, or chondrogenic (g-i) differentiation medium, the osteogenic, adipogenic, or chondrogenic differentiation of hBM-MSCs was assessed by specific staining. This test was repeated three times. Representative images were shown. Images were taken at 100x magnification. (a, d, and g) the <25-year-old group, (b, e, and h) the $>65$-year-old group, and (c, f, i) the $>65$-year-old+Rg1 group.

TCF, LEF, and C-myc increased, while the expression of GSK-3 $\beta$ decreased. After Rg1 treatment, $\beta$-catenin protein, TCF, LEF, and C-myc decreased, while GSK-3 $\beta$ expression increased (Figures $7(\mathrm{c})-7(\mathrm{f}))$.

\section{Discussion}

Myelofibrosis (MF) is referred to as myelin. It is a kind of myeloproliferative disease caused by collagen hyperplasia in bone marrow hematopoietic tissue, and its fibrous tissue seriously affects hematopoietic function. The age of onset is between 50 and 70 years old. Some scholars believe that myelofibrosis is caused by abnormal stimulation of hematopoietic stem cells, leading to fibrous tissue hyperplasia, even new bone formation, and bone marrow hematopoietic tissue involvement eventually leading to hematopoietic failure.

During the bone marrow puncture process, it was found that the older the patient, the greater the probability of "dry pumping". Statistics on bone marrow biopsy results show that as the age increases, the proportion of hematopoietic tissue and trabecular bone in human bone marrow decreases, while the proportion of adipose tissue increases.

In this study, hBM-MSCs were successfully isolated from the human bone marrow. The cultured hBM-MSCs displayed fibroblastic morphology. Previous experiments [44] have shown that the surface markers were similar to those of mesenchymal stem cells, expressing typical mesenchymal markers (CD73, CD90). The expression of cell surface antigens was consistent with the previously reported data of hBM-MSCs. hBM-MSCs can differentiate into osteoblasts, adipocytes, and chondroblasts in vitro. These results indicated that the isolated cells were identified as hBM-MSCs with the common characteristics of pluripotent stem cells.

Mesenchymal stem cells (MSC) are a kind of pluripotent stem cells belonging to the mesoderm [45]. The differentiation direction of mesenchymal stem cells is very important [45-50]. Therefore, it is of great significance to study methods to regulate the differentiation of mesenchymal stem cells. Traditional Chinese medicine is the inheritance of thousands of years of Chinese culture and civilization. It is regarded as a life science with Chinese characteristics. The theory of Traditional Chinese Medicine [24] holds that the stem cells belong to the "fundamental qi" of the body. Specifically, embryonic stem cells belong to "innate qi", while adult stem cells belong to "acquired qi". The situation of "qi" is linked to overall physical fitness. Ginsenoside is an essential medicine for "invigorating qi" in the clinical practice of traditional Chinese medicine. As the main active ingredient of $\mathrm{P}$. ginseng, Rg1 plays an important role in the treatment or adjuvant treatment of various diseases [51-54]. Can stem cell function be activated by replenishing "qi"? Can delay the aging of the body through make stem cell "qi" enough? All of these questions are worthy of in-depth discussion. 




(a)



(b)

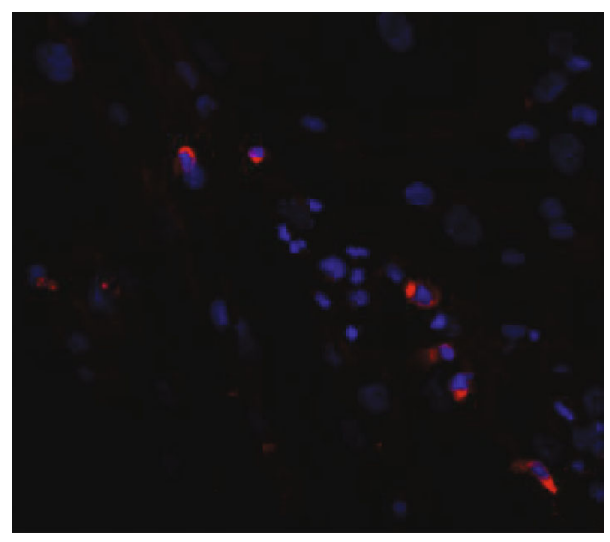

(c)


(d)

Figure 6: Continued. 


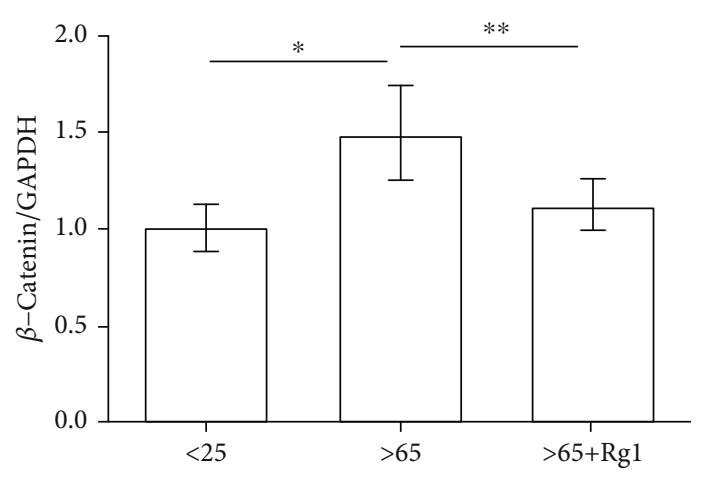

(e)
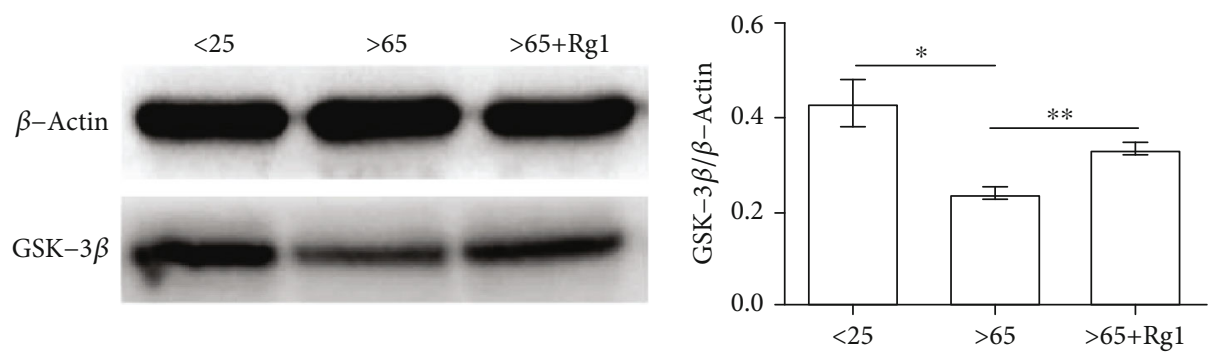

(f)
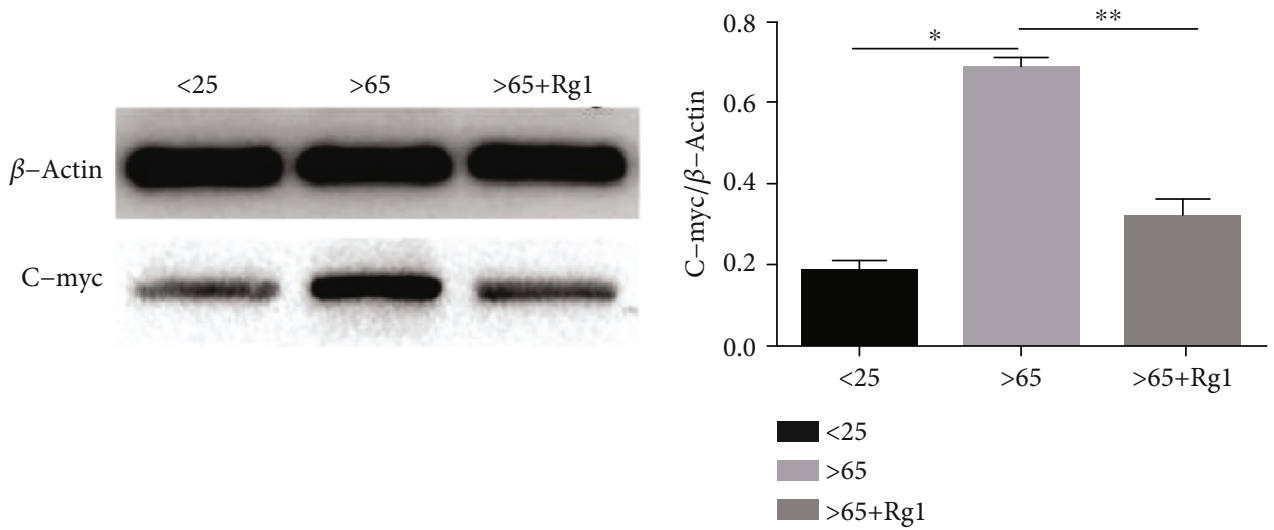

(g)


(h)

Figure 6: Continued. 


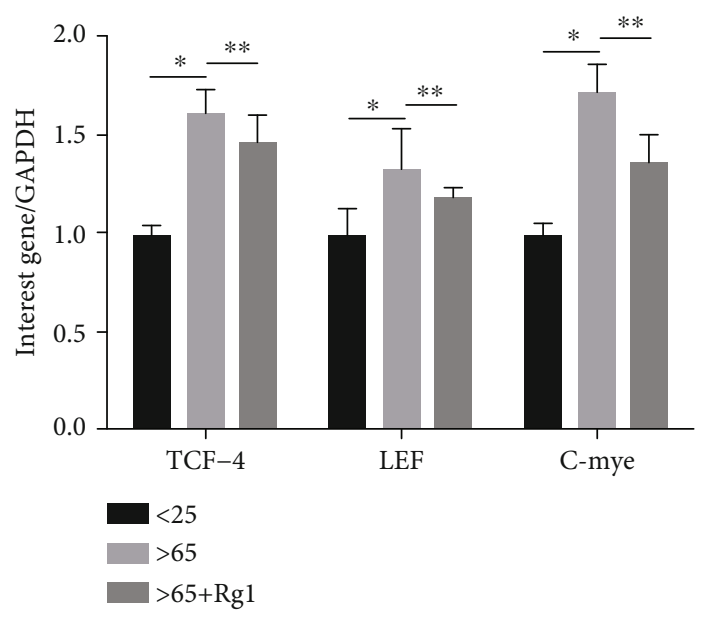

(i)

Figure 6: Effect of Rg1 on the expression of $\mathrm{Wnt} / \beta$-catenin signaling pathway-related proteins and mRNA in hBM-MSCs. (a-c) By immunofluorescence, PI (red) cells localize $\beta$-catenin, DAPI (blue) to visualize the nucleus. (a) the $<25$-year-old group, (b) the $>65$-yearold group, and (c) the $>65$-year-old+Rg1 group. This test was repeated three times. Representative images were shown. (d) Analysis of protein expression of $\beta$-catenin by Western blot. $\beta$-Actin was used as an internal control. (e, i) Analysis of mRNA of signaling pathwayrelated mRNA by RT-PCR; mRNA expression of GAPDH was used as an internal control. (f) Expression of GSK-3 $\beta$ protein was analyzed by Western blot. $(\mathrm{g}, \mathrm{h})$ Relative protein expression of LEF/TCF and C-myc proteins in different groups, and $\beta$-Actin was used as an internal control. $* * P<.05$ vs. the $>65$-year-old group, $* P<.05$ vs. the $<25$-year-old group.

Our study found that Rg1-inhibited Wnt/ $\beta$-catenin signaling pathway regulated the differentiation of hBM-MSCs. The Wnt/ $\beta$-catenin signaling pathway is a canonical pathway to regulate stem cell functions by regulating the localization of $\beta$-catenin, thus modulating the expression of downstream proteins and genes $[19,20,55]$. GSK-3 $\beta$ is an important part of the complex degrading $\beta$-catenin protein in the $\mathrm{Wnt} / \beta$ catenin signal pathway [55]. In the absence of Wnt signaling, $\beta$-catenin forms polyprotein complexes with Axin, APC (adenomatous polyposis coli), GSK $3 \beta$, and CK $1 \alpha$. Then, $\beta$ catenin is phosphorylated by the kinase in this complex and degraded by E3 ubiquitin ligase. TCF-4 and LEF are important binding sites of $\beta$-catenin protein after entering the nucleus. C-myc and Cyclin D1 genes are important target genes of the $\mathrm{Wnt} / \beta$-catenin signal pathway. Overactivation of the $\mathrm{Wnt} / \beta$-catenin signal pathway tends $\beta$-catenin protein to cluster together to enter into the nucleus. Overactivation of the $\mathrm{Wnt} / \beta$-catenin signaling pathway increases the production of $\beta$-catenin by degrading the complex of APC and GSK$3 \beta$. As the level of $\beta$-catenin in the cytoplasm increased, it will transfer to the nucleus and form a complex with family members such as transcription factor TCF/LEF [56-58]. By regulating the expression of target genes such as C-myc and cyclin $\mathrm{D} 1$, the physiological function of stem cells is regulated [20].

In this study, the mechanism of Rg1 delaying the senescence of mesenchymal stem cells was further investigated. As an inhibitor of GSK-3 $\beta$, Licl can activate the Wnt $/ \beta$ catenin signaling pathway and aggravate the senescence of mesenchymal stem cells. When ginsenoside $\mathrm{Rg} 1$ was added to the Licl group, it was seen that the ability of Rg1+Licl to form bone nodules and cartilage nodules was enhanced compared to the Licl group. It is shown that $\mathrm{Rg} 1$ can regulate the decrease of Licl-induced differentiation ability. Western blot showed that expression of $\beta$-catenin, TCF, C-myc, and LEF in the Rg1+Licl group decreased, and the expression of GSK- $3 \beta$ increased. These results indicate that ginsenoside Rg1 can interfere with the activation of the Wnt/ $\beta$-catenin signaling pathway and delay the senescence of hBM-MSCs.

However, the exact mechanism by which Rg1 regulates the $\mathrm{Wnt} / \beta$-catenin signaling pathway remains unclear. It has been reported [59] that $\mathrm{Rg} 1$ can antagonize oxidative stress injury and reduce the release of various oxidation factors in cells, including malonaldehyde (MDA) and reactive oxygen species (ROS). Previous studies $[60,61]$ have shown that $\operatorname{Rg} 1$ also have an anti-inflammatory effect in both cells and mice and reduce the expression and release of various inflammatory factor in cells, including interleukin-1 (IL-1), interleukin-6 (IL-6), and tumor necrosis factor- $\alpha$ (TNF- $\alpha$ ). Zhou et al. [62] found the generation of ROS and activation of NF- $\kappa \mathrm{B}$ transcription factor, which leads to induction of Wnt ligands such as Wnt1 and Wnt7a and activation of $\beta$-catenin. The finding showed that oxidative stress is an upstream regulator of $\mathrm{Wnt} / \beta$-catenin, a developmental signal usually silenced in normal adult kidney. Bi et al. [63] found that $\mathrm{Rg} 1$ can downregulate cytokine-cytokine receptor interaction, including RELT, TNFRSF8, TNFRSF6B, and EDA2R, which were able to bind tumor necrosis factor receptor-associated factor 1 or combine with Fas ligand TNFSF6 to induce cell death in cells that express this receptor molecule. $\beta$-Catenin and GSK- $3 \beta$ play a regulatory role in these processes [63]. Thus, we speculate that two possible mechanisms might be in charge of the Rg1regulated Wnt signaling pathway in this study. One is that Rg1 may reduce the expression and release of oxidation factors that cause the regulation of the Wnt signaling pathway. The other is that the gene downgrading by Rg1 can regulate phosphorylation of GSK-3 $\beta$ and $\beta$-catenin. However, this speculation needs to be further studied. 

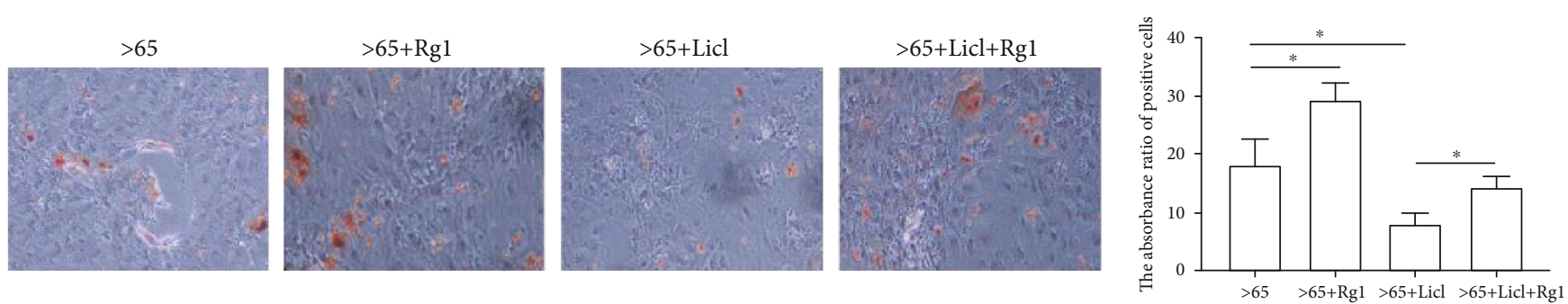

(a)
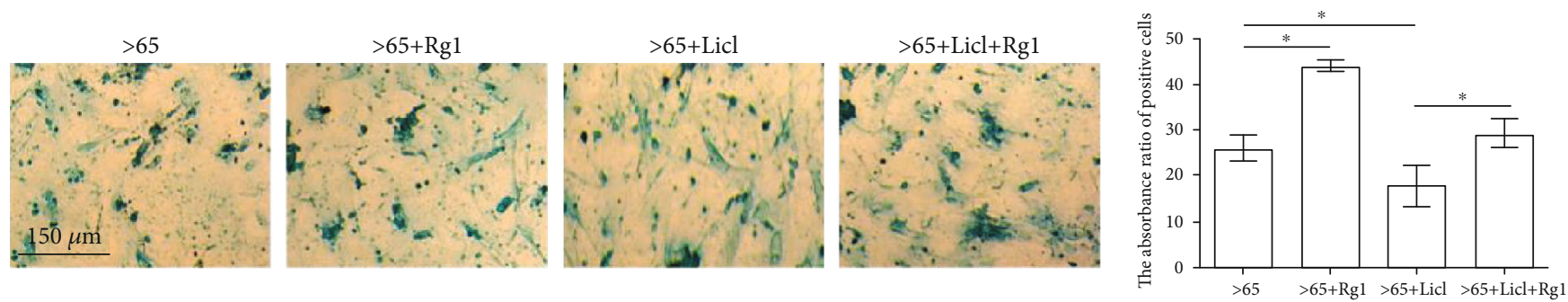

(b)



(c)



(d)

FIgure 7: Continued. 


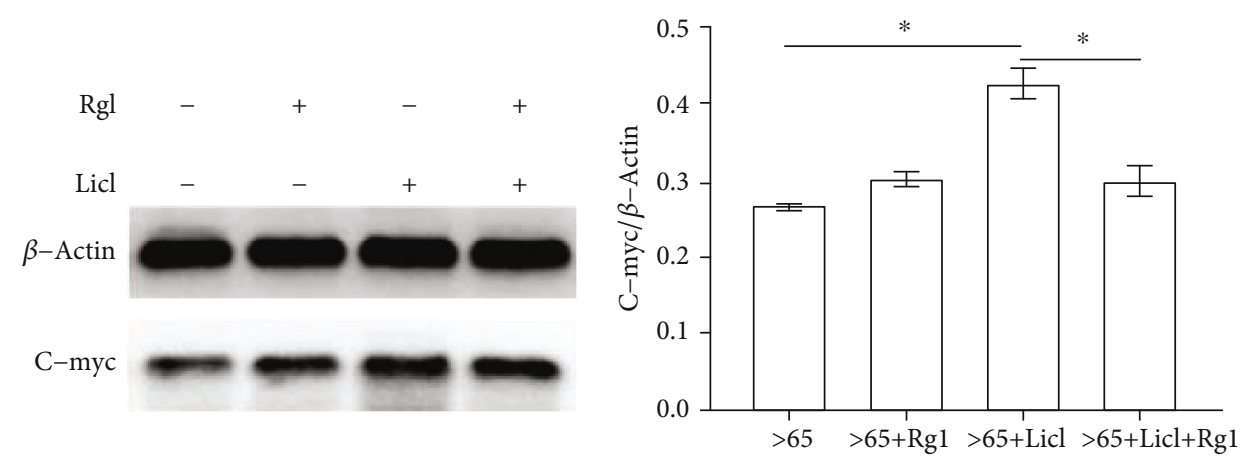

(e)
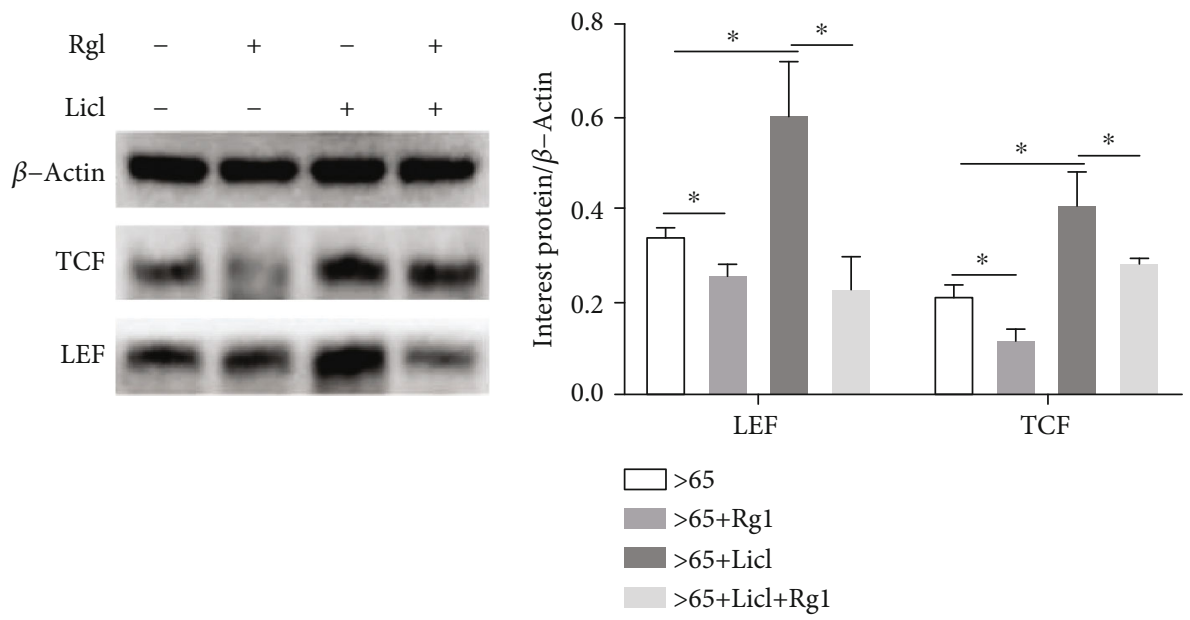

(f)

FIGURE 7: Rg1 regulates differentiation of senile mesenchymal stem cells (hBM-MSCs) related to GSK-3 $\beta$ Protein. Cell differentiation capacity was detected by differentiation culture assay in the presence or absence of Licl $(\mathrm{a}, \mathrm{b})$. This test was repeated three times. Representative images were shown. $\beta$-catenin, GSK-3 $\beta$, C-myc, TCF, and LEF were analyzed by Western blot (c-f). $* P<.05$.

In conclusion, $\operatorname{Rg} 1$ can regulate the differentiation of hBM-MSCs, and the Wnt/ $\beta$-catenin signaling pathway may be involved in this process. The findings of this study provide important experimental evidence for the application of Rg1 in the adjuvant therapy of MSCs.

\section{Data Availability}

Data sharing is not applicable to this article as no new data were created or analyzed in this study.

\section{Conflicts of Interest}

All authors declare no competing interests.

\section{Authors' Contributions}

Conceptualization is done by Yaping Wang. Data curation was performed by Ziling Wang, Minghe Xiao, and Li Ling. Funding acquisition was acquired by Yaping Wang. Methodology was performed by Rong Jiang, Lu Wang, Linbo Chen, and Xiongbin Chen. Project administration was performed by Ziling Wang and Yue Xiang. Writing the original draft was done by Ziling Wang.

\section{Acknowledgments}

This study was supported by the National Natural Science Foundation of China (No. 81673748).

\section{References}

[1] M. A. Goodell and T. A. Rando, "Stem cells and healthy aging," Science, vol. 350, no. 6265, pp. 1199-1204, 2015.

[2] G. Koliakos, "Stem cells and aging," Rejuvenation Research, vol. 20, no. 1, pp. 4-8, 2017.

[3] S. E. Artandi, H. M. Blau, G. de Haan et al., "Stem cells and aging: what's next?," Cell Stem Cell, vol. 16, no. 6, pp. 578$581,2015$.

[4] S. J. Morrison and A. C. Spradling, "Stem cells and niches: mechanisms that promote stem cell maintenance throughout life," Cell, vol. 132, no. 4, pp. 598-611, 2008.

[5] N. S. Chandel, H. Jasper, T. T. Ho, and E. Passegue, "Metabolic regulation of stem cell function in tissue homeostasis and organismal ageing," Nature Cell Biology, vol. 18, no. 8, pp. 823-832, 2016.

[6] L. M. Calvi and D. C. Link, "The hematopoietic stem cell niche in homeostasis and disease," Blood, vol. 126, no. 22, pp. 2443 2451, 2015. 
[7] B. A. Anthony and D. C. Link, "Regulation of hematopoietic stem cells by bone marrow stromal cells," Trends in Immunology, vol. 35, no. 1, pp. 32-37, 2014.

[8] N. Baker, L. B. Boyette, and R. S. Tuan, "Characterization of bone marrow-derived mesenchymal stem cells in aging," Bone, vol. 70, pp. 37-47, 2015.

[9] Y.-H. K. Yang, C. R. Ogando, C. W. See, T.-Y. Chang, and G. A. Barabino, "Changes in phenotype and differentiation potential of human mesenchymal stem cells aging in vitro," Stem Cell Research \& Therapy, vol. 9, no. 1, pp. 131-0876, 2018.

[10] Z. Shang, "[Kou Zongshi and his amplification of classics of Shen Nong's herbal] (chi)," Zhonghua Yi Shi Za Zhi, vol. 14, no. 3, pp. 146-149, 1984.

[11] Z. Mou, Q. Huang, S.-f. Chu et al., "Antidepressive effects of ginsenoside Rg1 via regulation of HPA and HPG axis," Biomedicine \& Pharmacotherapy, vol. 92, pp. 962-971, 2017.

[12] G. Y. Go, S. J. Lee, A. Jo et al., "Ginsenoside Rg1 from Panax ginseng enhances myoblast differentiation and myotube growth," Journal of Ginseng Research, vol. 41, no. 4, pp. 608614, 2017.

[13] J. S. Shim, M. Y. Song, S. V. Yim, S. E. Lee, and K. S. Park, "Global analysis of ginsenoside $\operatorname{Rg} 1$ protective effects in $\beta$ amyloid-treated neuronal cells," Journal of Ginseng Research, vol. 41, no. 4, pp. 566-571, 2017.

[14] C. Fan, Q. Song, P. Wang, Y. Li, M. Yang, and S. Y. Yu, "Neuroprotective effects of ginsenoside-Rg1 against depression-like behaviors via suppressing glial activation, synaptic deficits, and neuronal apoptosis in rats," Frontiers in Immunology, vol. 9, no. 2889, 2018.

[15] H. Yu, J. Zhen, Y. Yang, J. Gu, S. Wu, and Q. Liu, "Ginsenoside Rg1 ameliorates diabetic cardiomyopathy by inhibiting endoplasmic reticulum stress-induced apoptosis in a streptozotocin-induced diabetes rat model," Journal of Cellular and Molecular Medicine, vol. 20, no. 4, pp. 623-631, 2016.

[16] J. Shen, Z. Zhao, W. Shang et al., "Ginsenoside Rg1 nanoparticle penetrating the blood-brain barrier to improve the cerebral function of diabetic rats complicated with cerebral infarction," International Journal of Nanomedicine, vol. 12, pp. 6477-6486, 2017.

[17] G. Zu, J. Guo, N. Che, T. Zhou, and X. Zhang, "Protective effects of ginsenoside $\operatorname{Rg} 1$ on intestinal ischemia/reperfusion injury-induced oxidative stress and apoptosis via activation of the Wnt/ $\beta$-catenin pathway," Scientific Reports, vol. 6, no. $1,2016$.

[18] M. M. Murphy, A. C. Keefe, J. A. Lawson, S. D. Flygare, M. Yandell, and G. Kardon, "Transiently active Wnt/ $\beta$-catenin signaling is not required but must be silenced for stem cell function during muscle regeneration," Stem Cell Reports, vol. 3, no. 3, pp. 475-488, 2014.

[19] H. Clevers and R. Nusse, "Wnt/ $\beta$-catenin signaling and disease," Cell, vol. 149, no. 6, pp. 1192-1205, 2012.

[20] R. Nusse and H. Clevers, "Wnt/ $\beta$-catenin signaling, disease, and emerging therapeutic modalities," Cell, vol. 169, no. 6, pp. 985-999, 2017.

[21] C. M. Cruciat, "Casein kinase 1 and $\mathrm{Wnt} / \beta$-catenin signaling," Current Opinion in Cell Biology, vol. 31, pp. 46-55, 2014.

[22] A. Tian, H. Benchabane, Z. Wang, and Y. Ahmed, "Regulation of stem cell proliferation and cell fate specification by wingless/Wnt signaling gradients enriched at adult intestinal com- partment boundaries," PLOS Genetics, vol. 12, no. 2, article e1005822, 2016.

[23] C. Zhang, P. Chen, Y. Fei et al., "Wnt/ $\beta$-catenin signaling is critical for dedifferentiation of aged epidermal cells in vivo and in vitro," Aging Cell, vol. 11, no. 1, pp. 14-23, 2012.

[24] J. Li, D. Cai, X. Yao et al., "Protective effect of ginsenoside Rg1 on hematopoietic stem/progenitor cells through attenuating oxidative stress and the $\mathrm{Wnt} / \beta$-Catenin signaling pathway in a mouse model of d-galactose-induced aging," International Journal of Molecular Sciences, vol. 17, no. 6, p. 849, 2016.

[25] E. Rognoni, M. Widmaier, M. Jakobson et al., "Kindlin-1 controls Wnt and TGF- $\beta$ availability to regulate cutaneous stem cell proliferation," Nature Medicine, vol. 20, no. 4, pp. 350 359, 2014.

[26] J. M. Edelberg and V. L. T. Ballard, "Stem cell review series: regulating highly potent stem cells in aging: environmental influences on plasticity," Aging Cell, vol. 7, no. 4, pp. 599604,2008

[27] L. B. Hazeltine, J. A. Selekman, and S. P. Palecek, "Engineering the human pluripotent stem cell microenvironment to direct cell fate," Biotechnology Advances, vol. 31, no. 7, pp. 10021019, 2013.

[28] C. M. Metallo, J. C. Mohr, C. J. Detzel, J. J. dePablo, B. J. VanWie, and S. P. Palecek, "Engineering the stem cell microenvironment," Biotechnology Progress, vol. 23, no. 1, pp. 18-23, 2007.

[29] J. Richter, D. Traver, and K. Willert, "The role of Wnt signaling in hematopoietic stem cell development," Critical Reviews in Biochemistry and Molecular Biology, vol. 52, no. 4, pp. 414424, 2017.

[30] C. Ruiz-Herguido, J. Guiu, T. D'Altri et al., "Hematopoietic stem cell development requires transient $\mathrm{Wnt} / \beta$-catenin activity," The Journal of Experimental Medicine, vol. 209, no. 8, pp. 1457-1468, 2012.

[31] G. Siegel, T. Kluba, U. Hermanutz-Klein, K. Bieback, H. Northoff, and R. Schäfer, "Phenotype, donor age and gender affect function of human bone marrow-derived mesenchymal stromal cells," BMC Medicine, vol. 11, no. 1, pp. 1741$7015,2013$.

[32] E. A. Georgakopoulou, K. Tsimaratou, K. Evangelou et al., "Specific lipofuscin staining as a novel biomarker to detect replicative and stress-induced senescence. A method applicable in cryo-preserved and archival tissues," Aging, vol. 5, no. 1, pp. 37-50, 2013.

[33] P. Kanavaros, K. Stefanaki, D. Rontogianni et al., "Immunohistochemical expression of p 53, p 21/waf1, rb, p 16, cyclin D1, p27, Ki67, cyclin A, cyclin B1, bcl2, bax and bak proteins and apoptotic index in normal thymus," Histology and Histopathology, vol. 16, no. 4, pp. 1005-1012, 2001.

[34] A. H. Kisiel, L. A. McDuffee, E. Masaoud, T. R. Bailey, B. P. Esparza Gonzalez, and R. Nino-Fong, "Isolation, characterization, and in vitro proliferation of canine mesenchymal stem cells derived from bone marrow, adipose tissue, muscle, and periosteum," American Journal of Veterinary Research, vol. 73, no. 8, pp. 1305-1317, 2012.

[35] F. Luchetti, B. Canonico, D. Bartolini et al., "Melatonin regulates mesenchymal stem cell differentiation: a review," Journal of Pineal Research, vol. 56, no. 4, pp. 382-397, 2014.

[36] E. J. van Zoelen, I. Duarte, J. M. Hendriks, and S. P. van der Woning, "TGF $\beta$-induced switch from adipogenic to osteogenic differentiation of human mesenchymal stem cells: 
identification of drug targets for prevention of fat cell differentiation," Stem Cell Research \& Therapy, vol. 7, no. 1, pp. 0160375, 2016.

[37] B. D. Sui, C. H. Hu, C. X. Zheng, and Y. Jin, "Microenvironmental views on mesenchymal stem cell differentiation in aging," Journal of Dental Research, vol. 95, no. 12, pp. 13331340, 2016.

[38] L. Saulite, K. Jekabsons, M. Klavins, R. Muceniece, and U. Riekstina, "Effects of malvidin, cyanidin and delphinidin on human adipose mesenchymal stem cell differentiation into adipocytes, chondrocytes and osteocytes," Phytomedicine, vol. 53, pp. 86-95, 2019.

[39] W. Huang, P. Wang, T. Shen et al., "Aluminum trichloride inhibited osteoblastic proliferation and downregulated the Wnt/ $\beta$-catenin pathway," Biological Trace Element Research, vol. 177, no. 2, pp. 323-330, 2017.

[40] R. G. Oas, B. A. Nanes, C. C. Esimai, P. A. Vincent, A. J. García, and A. P. Kowalczyk, "p120-catenin and $\beta$-catenin differentially regulate cadherin adhesive function," Molecular Biology of the Cell, vol. 24, no. 6, pp. 704-714, 2013.

[41] M. Vinyoles, B. Del Valle-Pérez, J. Curto et al., "Multivesicular GSK3 sequestration upon Wnt signaling is controlled by p120catenin/cadherin interaction with LRP5/6," Molecular Cell, vol. 53, no. 3, pp. 444-457, 2014.

[42] A. Castañeda, C. Serrano, J. A. Hernández-Trejo et al., "pVHL suppresses Akt/ $\beta$-catenin-mediated cell proliferation by inhibiting 14-3-3 $\zeta$ expression," The Biochemical Journal, vol. 474, no. 16, pp. 2679-2689, 2017.

[43] L. Wu, Q. Wei, Y. Lv et al., "Wnt/ $\beta$-Catenin pathway is involved in cadmium-induced inhibition of osteoblast differentiation of bone marrow mesenchymal stem cells," International Journal of Molecular Sciences, vol. 20, no. 6, p. 1519, 2019.

[44] X. Chen, L. Wang, J. Hou et al., "Study on the dynamic biological characteristics of human bone marrow mesenchymal stem cell senescence," Stem Cells International, vol. 2019, Article ID 9271595, 9 pages, 2019.

[45] A. I. Caplan, "Mesenchymal stem cells," Journal of Orthopaedic Research, vol. 9, no. 5, pp. 641-650, 1991.

[46] Z. Zhang, F. Nör, M. Oh, C. Cucco, S. Shi, and J. E. Nör, "Wnt/ $\beta$-catenin signaling determines the vasculogenic fate of postnatal mesenchymal stem cells," Stem Cells, vol. 34, no. 6, pp. 1576-1587, 2016.

[47] A. Reinisch, N. Etchart, D. Thomas et al., "Epigenetic and in vivo comparison of diverse MSC sources reveals an endochondral signature for human hematopoietic niche formation," Blood, vol. 125, no. 2, pp. 249-260, 2015.

[48] L. Tomasello, R. Mauceri, A. Coppola et al., "Mesenchymal stem cells derived from inflamed dental pulpal and gingival tissue: a potential application for bone formation," Stem Cell Research \& Therapy, vol. 8, no. 1, pp. 179-0633, 2017.

[49] A. Uccelli, L. Moretta, and V. Pistoia, "Mesenchymal stem cells in health and disease," Nature Reviews. Immunology, vol. 8, no. 9, pp. 726-736, 2008.

[50] M. H. Park, R. Subbiah, M. J. Kwon et al., "The three dimensional cues-integrated-biomaterial potentiates differentiation of human mesenchymal stem cells," Carbohydrate Polymers, vol. 202, pp. 488-496, 2018.

[51] C. Ning, X. Gao, C. Wang et al., "Protective effects of ginsenoside Rg1 against lipopolysaccharide/d-galactosamine-induced acute liver injury in mice through inhibiting toll-like receptor
4 signaling pathway," International Immunopharmacology, vol. 61, pp. 266-276, 2018.

[52] C. Fan, X. Zhu, Q. Song, P. Wang, Z. Liu, and S. Y. Yu, "MiR134 modulates chronic stress-induced structural plasticity and depression- like behaviors via downregulation of Limk1/cofilin signaling in rats," Neuropharmacology, vol. 131, pp. 364-376, 2018.

[53] Y. Li, F. Wang, and Y. Luo, "Ginsenoside Rg1 protects against sepsis-associated encephalopathy through beclin 1-independent autophagy in mice," Journal of Surgical Research, vol. 207, pp. 181-189, 2017.

[54] Y. Y. Tang, W. X. Guo, Z. F. Lu, M. H. Cheng, Y. X. Shen, and Y. Z. Zhang, "Ginsenoside Rg1 promotes the migration of olfactory ensheathing cells via the PI3K/Akt pathway to repair rat spinal cord injury," Biological \& Pharmaceutical Bulletin, vol. 40, no. 10, pp. 1630-1637, 2017.

[55] H. Huang and X. He, "Wnt/beta-catenin signaling: new (and old) players and new insights," Current Opinion in Cell Biology, vol. 20, no. 2, pp. 119-125, 2008.

[56] H. Yamamoto, M. Ihara, Y. Matsuura, and A. Kikuchi, "Sumoylation is involved in beta-catenin-dependent activation of Tcf-4," The EMBO Journal, vol. 22, no. 9, pp. 2047-2059, 2003.

[57] T. Valenta, J. Lukas, L. Doubravska, B. Fafilek, and V. Korinek, "HIC1 attenuates Wnt signaling by recruitment of TCF-4 and beta-catenin to the nuclear bodies," The EMBO Journal, vol. 25, no. 11, pp. 2326-2337, 2006.

[58] I. Egashira, F. Takahashi-Yanaga, R. Nishida et al., "Celecoxib and 2,5-dimethylcelecoxib inhibit intestinal cancer growth by suppressing the $\mathrm{Wnt} / \beta$-catenin signaling pathway," Cancer Science, vol. 108, no. 1, pp. 108-115, 2017.

[59] J. Ma, J. Liu, Q. Wang, H. Yu, Y. Chen, and L. Xiang, “The beneficial effect of ginsenoside Rg1 on Schwann cells subjected to hydrogen peroxide induced oxidative injury," International Journal of Biological Sciences, vol. 9, no. 6, pp. 624-636, 2013.

[60] T. Tao, F. Chen, L. Bo et al., "Ginsenoside Rg1 protects mouse liver against ischemia-reperfusion injury through antiinflammatory and anti-apoptosis properties," The Journal of Surgical Research, vol. 191, no. 1, pp. 231-238, 2014.

[61] J. Li, C. Yang, S. Zhang et al., "Ginsenoside Rg1 inhibits inflammatory responses via modulation of the nuclear factor- $\kappa \mathrm{B}$ pathway and inhibition of inflammasome activation in alcoholic hepatitis," International Journal of Molecular Medicine, vol. 41, no. 2, pp. 899-907, 2018.

[62] L. Zhou, X. Chen, M. Lu et al., "Wnt/ $\beta$-catenin links oxidative stress to podocyte injury and proteinuria," Kidney International, vol. 95, no. 4, pp. 830-845, 2019.

[63] S. Bi, X. Ma, Y. Wang et al., "Protective effect of ginsenoside Rg1 on oxidative damage induced by hydrogen peroxide in chicken splenic lymphocytes," Oxidative Medicine and Cellular Longevity, vol. 2019, Article ID 8465030, 13 pages, 2019. 